\title{
Erratum to: Low Specificity of a Malaria Rapid Diagnostic Test During an Integrated Community Case Management Trial
}

Alfred B. Tiono $\cdot$ Amidou Diarra $\cdot$ Souleymane Sanon $\cdot$

Issa Nébié • Amadou T. Konaté • Franco Pagnoni •

Sodiomon B. Sirima

To view enhanced content go to www.infectiousdiseases-open.com

Published online: November 9, 2013

(c) The Author(s) 2013. This article is published with open access at Springerlink.com

Erratum to: Infect Dis Ther (2013) 2:27-36

DOI 10.1007/s40121-013-0006-6

The editors of Infectious Diseases and Therapy would like to make the following addition to the Acknowledgments section of the abovementioned paper. This required wording was unintentionally missed off the original version of the manuscript.

"Compliance with Ethics Guidelines: All procedures followed were in accordance with

The online version of the original article can be found under doi:10.1007/s40121-013-0006-6.

A. B. Tiono $(\bowtie) \cdot$ A. Diarra · S. Sanon · I. Nébié ·

A. T. Konaté · S. B. Sirima

Centre National de Recherche et de Formation sur le

Paludisme (CNRFP), 01 BP 2208, Ouagadougou 01,

Burkina Faso

e-mail: t.alfred@fasonet.bf

F. Pagnoni

Evidence for Antimalarial Policy and Access Unit, UNICEF/UNDP/World Bank/WHO Special

Programme for Research and Training in Tropical

Diseases (TDR), Geneva, Switzerland

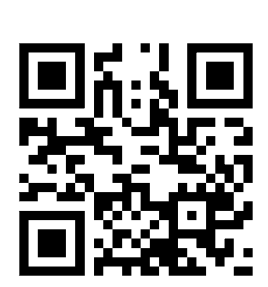

Enhanced content for this article is

available on the journal web site:

www.infectiousdiseases-open.com the ethical standards of the responsible committee on human experimentation (institutional and national) and with the Helsinki Declaration of 1975, as revised in 2000 and 2008. Informed consent was obtained from all patients for being included in the study."

Open Access. This article is distributed under the terms of the Creative Commons Attribution Noncommercial License which permits any noncommercial use, distribution, and reproduction in any medium, provided the original author(s) and the source are credited. 